Jacek F. Nowak

Uniwersytet Ekonomiczny w Poznaniu

e-mail:j.nowak@ue.poznan

\title{
Współpraca międzysamorządowa w polityce rozwoju zorientowanej terytorialnie a wyznaczanie granic miejskich obszarów funkcjonalnych
}

\begin{abstract}
Zarys treści: Artykuł zawiera omówienie polityki rozwoju zorientowanej terytorialnie jako wiodącej obecnie koncepcji rozwoju propagującej wspóldziałanie wzajemne podmiotów sektora publicznego, a zwłaszcza jednostek samorządu terytorialnego, oraz jednostek sektora społecznego i prywatnego. Wyrazem realizacji tej polityki jest powstawanie partnerstw międzysamorządowych $w$ celu skutecznego programowania i realizowania ponadlokalnego rozwoju w obrębie tworzących się obszarów funkcjonalnych. Organizowanie wsparcia z poziomu krajowego, regionalnego i Unii Europejskiej dla rozwoju miejskich obszarów funkcjonalnych wiąże się z wyznaczaniem granic tych obszarów. Artykuł podkreśla wagę uwzględniania istniejących zakresów działania partnerstw międzysamorządowych w procesach wyznaczania zasięgu miejskich obszarów funkcjonalnych. Jest to istotne, szczególnie jeżeli celem ich działania ma być koordynacja polityki rozwoju, realizacja wspólnych projektów infrastrukturalnych oraz wspólne dostarczanie usług publicznych.
\end{abstract}

Słowa kluczowe: polityka rozwoju zorientowana terytorialnie, miejskie obszary funkcjonalne, partnerstwa międzysamorządowe

\section{Wprowadzenie}

W ostatnich dziesięcioleciach w Polsce rozwija się dyskusja o znaczeniu powiązań między miastami a otaczającymi je obszarami wiejskimi (Czyż 2009, KSRR 2020 2010, KPZK 2030 2012). Jednocześnie powszechnie obserwowane zjawisko suburbanizacji uwidoczniło problemy wynikające $z$ braku kompleksowego planowania i koordynacji rozwoju miast i stref podmiejskich (Lisowski, Grochowski 2008). Zasadniczo na poziomie lokalnym planowanie przestrzenne oraz strategiczne ogranicza się do obszaru poszczególnych gmin (Nowak 2010). W małym stopniu zapobiega to działaniom indywidualnych inwestorów zmierzających zazwyczaj do osiągania krótkoterminowych, indywidualnych celów, które nie są 
koordynowane $z$ inwestycjami publicznymi i działaniami prowadzonymi w sąsiednich gminach. Często te indywidualne działania nie są zgodne $z$ zasadami rozwoju zrównoważonego lub wywołują niekorzystny wpływ na tereny położone w sąsiednich gminach. W ocenie efektywności działań samorządowych także dominuje analiza ograniczona do poszczególnych jednostek samorządu terytorialnego. Na wszystkich poziomach administracji publicznej dostrzegana jest coraz powszechniej potrzeba koordynacji procesów rozwojowych w skali obszarów funkcjonalnych, zwłaszcza tych o charakterze miejskim obejmujących centralny obszar miejski i powiązany z nim teren wiejski (Nowak, Perska 2014). Roli koordynacyjnej w skali lokalnej nie spełniają działania planistyczne realizowane na poziomie regionalnym dotyczące gospodarki przestrzennej i strategii rozwoju (Chądzyński i in. 2007).

Celem artykułu jest zwrócenie uwagi na znaczenie uwzględniania zasięgu działania partnerstw międzysamorządowych przy określaniu granic miejskich obszarów funkcjonalnych odgrywających kluczową rolę w realizacji polityki rozwoju zorientowanej terytorialnie. Zasadniczo możemy wyróżnić dwa podejścia w tym zakresie. Najczęściej stosowane jest wyznaczanie zasięgu miejskich obszarów funkcjonalnych w oparciu o analizę wybranych wskaźników statystycznych opisujących siłę powiązań między miastem centralnym a jego otoczeniem oraz wskaźników ilustrujących występowanie społecznych, gospodarczych i przyrodniczych cech obszarów znajdujących się pod wpływem ośrodka miejskiego (Markowski, Marszał 2006, s. 15-16, Smętkowski i in. 2009 s. 62-72, Śleszyński 2013). Dobór wskaźników i metoda wyznaczania zasięgu powinna wynikać z celu, jakiemu służy dana metoda delimitacji. Podejście oparte na wykorzystaniu wskaźników statystycznych jest $w$ pełni uzasadnione, gdy przy prowadzeniu analizy dominują cele poznawcze. Drugi rodzaj podejścia do wyznaczania granic obszarów funkcjonalnych jest potrzebny, gdy zamierzamy określić obszary funkcjonalne dla celów prowadzenia wspólnej polityki rozwojowej lub obszar koordynacji współdziałania przy dostarczaniu usług. $W$ tej sytuacji niesłychanie istotną kwestią jest rozpoznanie faktycznej współpracy między jednostkami samorządowymi w ramach funkcjonujących partnerstw. Tworzenie rzeczywistych skutecznych partnerstw wymaga $z$ reguly czasu na zbudowanie zaufania między partnerami oraz rozwinięcia nastawienia na współpracę i umiejętności budowania kompromisów i osiągania wspólnie uzgodnionych celów (Nowak 2012).

\section{Polityka rozwoju zorientowana terytorialnie}

Od lat 90. XX w. obserwujemy wyłanianie się „nowej polityki regionalnej”, która wypiera stopniowo tradycyjne podejście do kreowania rozwoju regionalnego dominujące w drugiej połowie XX w. (OECD 2009, s. 49-51, KSRR 2020 2010, s. 14-18). W tradycyjnym podejściu dominowały cele związane $z$ równoważeniem narodowych gospodarek poprzez stosowanie sektorowego podejścia przez rządy centralne. Analizy, planowanie działań i ocena ich skuteczności były zazwyczaj dokonywane w skali regionów administracyjnych i krajów. Skupiano się na wspie- 
raniu rozwoju w regionach osiągających najniższe wyniki, przez co dążono do wyrównywania warunków życia między regionami. Głównymi narzędziami stosowanymi w ramach realizowania tradycyjnej polityki regionalnej były różnego typu centralne subsydia, zachęty finansowe, krajowa lub międzynarodowa pomoc czy regulacje dające przywileje regionom zapóźnionym w rozwoju. Przedstawione tradycyjne podejście do polityki regionalnej było wynikiem licznych poszukiwań teoretycznych (Kisiała, Stępiński 2013) oraz było stosowane w różnych odmianach w poszczególnych krajach Unii Europejskiej (Winiarski, Winiarska 2006, s. 286, 305). Krajowe polityki regionalne różniły się, zwłaszcza stosowanymi instrumentami oddziaływania na regiony, jednak podstawowy nurt był zbliżony i kładł nacisk na wspieranie regionów o niższym poziomie rozwoju poprzez stosowanie podejścia sektorowego (OECD 2009).

Nowa polityka regionalna (Olechnicka, Wojnar 2013, s. 7-9), która zaczęła rozwijać się w latach $90 \mathrm{XX}$ w., skupia się na stymulowaniu maksymalnego wzrostu na wszystkich obszarach proporcjonalnie do istniejących możliwości poprzez uruchamianie zintegrowanych programów i projektów. Dąży się do przezwyciężenia podejścia sektorowego. Głównymi obiektami analizy i oddziaływania są obszary funkcjonalne, najczęściej miejskie, a zwłaszcza metropolitalne. Tracą na znaczeniu ograniczenia wynikające z przebiegu granic administracyjnych, a nawet państwowych w wyniku rozwoju procesów globalizacyjnych i konsolidacyjnych. Oprócz dostępu do sieci powiązań z globalną gospodarką, co zwiększa rolę obszarów metropolitalnych, liczy się lokalna konsolidacja, współpraca międzysektorowa i kreatywność pozwalające wyróżnić się oraz oferować rozmaite innowacje, które są motorem rozwoju (Florida 2005). Ważnymi instrumentami wykorzystywanymi w nowej polityce regionalnej są miękka i twarda infrastruktura umożliwiająca wykorzystanie lokalnych i regionalnych zasobów (OECD 2009, s. 49-51). Głównymi aktorami są tu współdziałające ze sobą w układach poziomych i pionowych jednostki administracji publicznej, od rządu centralnego po władze lokalne, oraz organizacje gospodarcze i społeczne. Istotną rolę w kreowaniu, a zwłaszcza we wdrażaniu polityki rozwoju przypisuje się specjalnie powoływanym agencjom rozwoju, które realizując część zadań publicznych, pozwalają pokonać ograniczenia biurokratyczne dzięki stosowaniu rozwiązań instytucjonalnych właściwych dla sektora prywatnego.

Przedstawiona zmiana paradygmatu polityki regionalnej znalazła wyraz w polityce regionalnej prowadzonej przez Unię Europejską, gdzie wcześniej dążono do uzyskania spójności gospodarczej i społecznej, starając się wspierać regiony najbardziej opóźnione w rozwoju. Narastająca konkurencja globalna zmusiła kraje europejskie do zmiany polityki regionalnej i podkreślenia wagi wsparcia obszarów mających szanse skutecznie konkurować ze światowymi liderami (Grosse 2008). Uznano, że największe szanse w globalnej konkurencji mają obszary skupiające działalność innowacyjną, przyciągające najlepiej wykwalifikowanych pracowników, oferujące wysoką jakość życia i powiązane z światowymi centrami rozwoju (Smętkowski 2013). Do takich obszarów należą strefy zurbanizowane w obrębie miejskich obszarów funkcjonalnych, a zwłaszcza obszary metropolitalne. W efekcie jako istotny element polityki rozwoju przyjęto zintegrowane podej- 
ście terytorialne (integrated territorial approach) przedstawione w ramach zielonej księgi w sprawie spójności terytorialnej (EC 2008), które zakłada wykorzystywanie endogenicznych zasobów na obszarach funkcjonalnych.

Zamiar wspierania rozwoju miejskich obszarów funkcjonalnych w ramach nowej unijnej polityki regionalnej jest wyraźnie widoczny w uruchomieniu wsparcia dla obszarów problemowych czy obszarów strategicznej interwencji (MRR 2009) oraz dla zintegrowanych inwestycji terytorialnych (MRR 2013). W obu tych formach wsparcie skierowane jest do grup jednostek terytorialnych, które w ten sposób są zachęcane do współdziałania przy analizie wspólnych potrzeb, przygotowywaniu długookresowego planu działania i wdrażaniu wspólnych projektów.

Polityka rozwoju zorientowana terytorialnie stara się osiągnąć efekt synergii przez działania skoordynowane terytorialnie i instytucjonalnie. Podejście to rozwinęło się w toku poszukiwań dróg poprawy sytuacji konkurencyjnej Unii Europejskiej w ujęciu globalnym. Wynikało ono ze strategii lizbońskiej opublikowanej w 2000 r. i później było kontynuowane w ramach strategii Europa 2020 (KE 2010). W tych dokumentach strategicznych uznano, że należy dbać o intensywny rozwój obszarów, które mają szanse skutecznie uczestniczyć w konkurencji globalnej. Dlatego skoncentrowano uwagę na wypracowaniu instrumentów wspierających tereny generujące innowacje. Analizy ESPON wskazały, że obszarami wdrażającymi innowacje produktowe i procesowe najczęściej są rejony silnie zurbanizowane, w tym stołeczne $w$ poszczególnych państwach $i$ inne miejskie obszary funkcjonalne (Olechnicka, Wojnar 2014, s. 59-74). Chodzi przede wszystkim o tereny, które zapewniają najlepsze warunki dla lokalizacji działalności badawczej i wdrożeniowej oraz oferują doskonałe warunki życia dla pracowników o wysokich kwalifikacjach.

Dla skuteczności podejścia rozwoju zorientowanego terytorialnie ważne jest, aby było ono realizowane nie tylko w fazie programowania. Podejście to, aby osiągnąć powodzenie, należy stosować także w trakcie wdrażania, monitorowania i ewaluacji. Wymaga ono zasadniczych zmian w modelu funkcjonowania administracji publicznej. Postulowane jest przełamanie biurokratycznego modelu działania administracji publicznej. Jednymi z najbardziej aktualnych koncepcji funkcjonowania jednostek administracji publicznej, które mogą umożliwić realizowanic podejścia zintegrowanego terytorialnie, jest zarządzanie wielopoziomowe (multi-level governance) oraz partnerstwo międzysamorządowe (Inter Municipal Cooperation IMC) (Hulst i in. 2009). Pozwalają one obniżać koszty organizowania usług publicznych i poprawiać ich jakość przez zwiększanie skali działań, wykorzystywanie zawansowanych technologii i zatrudnianie specjalistów (Ansell, Gash 2008). Jednocześnie stosowanie zaleceń wynikających z tych koncepcji umożliwia utrzymanie demokratycznie wyłonionej władzy samorządowej blisko społeczeństwa dzięki pozostawieniu małych jednostek administracyjnych jako podstawy organizacji władz publicznych. Szeroka akceptacja społeczna dla utrzymania dotychczasowych zasięgów działania władz lokalnych wiąże się często $z$ rozwiniętym historycznie poczuciem tożsamości lokalnej, które jest ważne w wielu państwach europejskich (Piasecki 2009). 


\section{Doświadczenia europejskie w zakresie funkcjonowania partnerstw międzysamorządowych}

Samorządy lokalne są trwałym elementem systemów administracji politycznej we współczesnej Europie, który jest uznawany za nieodłączny wymóg gwarancji istnienia demokracji w poszczególnych państwach. Powszechna w państwach Europy Zachodniej, w tym w tych należących do Unii Europejskiej, jest tradycja i moźliwość podejmowania współdziałania przez samorządy lokalne (Hulst i in. 2009), co dobrze wpisuje się w obecną tendencję do wspierania rozwoju zorientowanego terytorialnie. Poszczególne kraje stosowały różne modele współpracy międzysamorządowej. Badania porównawcze wskazują, że znaczną rolę w proces powstawania partnerstw międzysamorządowych odgrywa aktywność rządu centralnego w państwach unitarnych czy też władz landów lub prowincji w państwach federalnych (Hulst, van Montfort 2011). Polityka władz odpowiedzialnych za kształtowanie całości systemu administracyjnego może stymulować takie inicjatywy samorządów lokalnych czy nawet wymuszać powstawanie partnerstw. Efekty takie można osiągnąć, wdrażając rozwiązania legislacyjne nakłaniające do tworzenia określonych rodzajów partnerstw lub stosując standardy dostarczania usług publicznych wymuszające współdziałanie. Niektóre rządy przygotowywały nowe rozwiązania prawne wprowadzające niedostępne wcześniej formy współpracy jednostek samorządu terytorialnego. Często stosowano także bodźce finansowe w celu zmobilizowania ich do współdziałania.

Za istotny element skuteczności działań kooperacyjnych samorządów lokalnych uznawana jest też kultura organizacyjna charakterystyczna dla poszczególnych państw czy regionów. Doświadczenia państw Europy Zachodniej wskazują, że w niektórych państwach politycy lokalni i pracownicy administracji dzięki umiejętnościom kooperacyjnym potrafią organizować partnerstwa nawet mimo mało sprzyjających rozwiązań legislacyjnych (Hulst i in. 2009). W Europie Środkowo-Wschodniej wykorzystywane są doświadczenia państw Europy Zachodniej w zakresie kooperacji dla efektywniejszego i skuteczniejszego dostarczania usług publicznych oraz lepszej koordynacji działań samorządów lokalnych. Kwestia wspólpracy jednostek samorządu terytorialnego jest też ważna w państwach Europy Środkowo-Wschodniej i Południowej, gdzie dominują małe jednostki samorządu terytorialnego. Rada Europy oraz UNDP ${ }^{1}$ prowadzi od kilkunastu lat działania wspierające proces upowszechniania wiedzy na temat korzyści powoływania partnerstw międzysamorządowych. Dostępne są opisy dobrych praktyk w dziedzinie organizowania partnerstw samorządowych ${ }^{3}$ promujące zwiększenie

$1 \quad$ Polityka UNDP w Europie Środkowej, Wschodniej i Poludniowej w dziedzinie wspierania współpracy międzysamorządowej jest przedstawiona na stronie: http://www.municipal-cooperation. org/index.php? title=Main Page (dostęp: 6.08.14).

2 Przykładem jest podręcznik opracowany w 2010 na zlecenie Rady Europy i UNDP dostępny pod adresem: http://www.municipal-cooperation.org/images/4/4c/IMC_Toolkit_Manual.pdf (dostęp: 6.08.14).

3 Przykładem może być podręcznik dobrych praktyk w dziedzinie współpracy międzysamorządowej opracowany w 2007 na zlecenie Radu Europy dostępny pod adresem: http://www.migm.gov.tr/ AvrupaKonseyi/Ek33.pdf (dostęp: 6.08.14). 
skali działania w dziedzinie świadczenia usług publicznych w celu podniesienia ich efektywności. Państwa te ciągle jeszcze zdobywają doświadczenie w funkcjonowaniu demokratycznych samorządów lokalnych i dzięki niewielkim rozmiarom umożliwiają utrzymanie bliskiego kontaktu władz lokalnych z obywatelami. Jednocześnie często brakuje w tych krajach kultury organizacyjnej nastawionej na współpracę.

Dość istotna w stymulowaniu powstawania partnerstw jest możliwość korzystania ze wsparcia funduszy zewnętrznych, np. w ramach projektów Unii Europejskiej, które często mają skalę wymagającą podejmowania współpracy przez samorządy lokalne. Takie podejście będzie się nasilało w ramach nowej perspektywy finansowej UE w okresie 2014-2020. Obecnie poszukuje się metod zachowania równowagi między korzyściami realizacji działań w formie partnerstw oraz utrzymaniu kontroli społecznej nad nowymi formami organizacyjnymi.

\section{Tendencje w Polsce w zakresie powstawania partnerstw międzysamorządowych}

W Polsce po przywróceniu samorządów terytorialnych, zgodnie z ustawą o samorządzie gminnym z 1990 r. i prawem o stowarzyszeniach z 1989 r., jednostki samorządu terytorialnego miały możliwość stowarzyszania się i współdziałania w zakresie wykonywania zadań własnych. Szczególnym zainteresowaniem samorządów cieszyło się podejmowanie współdziałania $w$ formie stowarzyszeń, ponieważ umożliwiało reprezentowanie ich interesów wobec administracji rządowej. Powstające stowarzyszenia stawiały sobie za cel także wymianę doświadczeń czy promocję działań samorządowych (Dolnicki 2012). Mniejszą aktywność jednostki samorządu lokalnego wykazywały w podejmowaniu współpracy w dziedzinie wspólnego świadczenia usług publicznych, ponieważ powszechne w latach 90. XX w. było dążenie do budowania niezależności i korzystanie z moźliwości organizowania działań w skali poszczególnych samorządów. Wspólne dostarczanie usług w formie porozumień, związków międzygminnych czy spółek komunal-

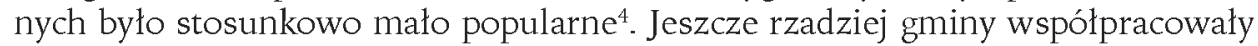
w tym czasie w zakresie planowania czy koordynacji działań.

Z czasem zaczęto dostrzegać w samorządach terytorialnych coraz bardziej potrzebę współdziałania $w$ celu reprezentowania wspólnych interesów oraz przede wszystkim efektywniejszego i lepszego dostarczania usług. W efekcie rosła liczba porozumień komunalnych oraz związków międzygminnych czy spółek komunalnych ${ }^{5}$. Pewnym wsparciem dla działań konsolidacyjnych były projekty finansowa-

4 Np. w stosunku do gmin norweskich, które średnio uczestniczą w 8 partnerstwach, w większości związanych z dostarczaniem usług - dane Norweskiego Związku Władz Lokalnych i Regionalnych z 2012 r.

$5 \quad$ Wyniki ogólnopolskiej ankiety przeprowadzonej w 2012 r. wśród samorządów w ramach projektu „Budowanie kompetencji do wspólpracy międzysamorządowej i międzysektorowej jako narzędzi rozwoju lokalnego i regionalnego". 
ne przez Unię Europejską, Bank Światowy i inne organizacje lub kraje udzielające pomocy, które często ze względu na skalę lub charakter wymagały zawiązywania partnerstw przez chcące w nich uczestniczyć jednostki samorządu terytorialnego. W niektórych przypadkach takie projekty stawały się początkiem dłuższej współpracy. Jednak w pierwszej dekadzie XXI w. brakowało zdecydowanej polityki centralnej wspierającej wspólne działania gmin w zakresie dostarczania usług publicznych czy organizowania działań dla zaczynających się rozwijać obszarów funkcjonalnych przekraczających granice administracyjne jednostek lokalnych. Szczególnie brak skuteczności polityki centralnej w dziedzinie wspierania współpracy samorządów było widać w niemożności przyjęcia rozwiązań legislacyjnych dla powstających obszarów metropolitalnych wokól największych miast polskich (Lackowska 2009).

\section{Obszary funkcjonalne $\mathrm{w}$ polskiej polityce regionalnej}

Istotnym bodźcem do powstawania obszarów funkcjonalnych w Polsce jest obecnie stosowanie w UE zintegrowanego podejścia terytorialnego (integrated territorial approach), które zakłada wykorzystywanie endogenicznych zasobów w ramach obszarów przekraczających granice administracyjne, ale mających więzi funkcjonalne (Zielona księga w sprawie spójności terytorialnej 2008). Zgodna z tym podejściem „Krajowa Strategia Rozwoju Regionalnego 2010-2020” (KSRR 2010) założyła przejście od układu sektorowego do układu terytorialnego. Potwierdzeniem tego podejścia jest Koncepcja Przestrzennego Zagospodarowania Kraju (KPZK 2030 2012), która przyjęła obszary funkcjonalne jako podstawowe jednostki przestrzenne, w których będzie odbywał się rozwój społeczno-gospodarczy.

Zasadniczo wyróżniono miejskie, wiejskie i problemowe obszary funkcjonalne. Najważniejsza jest rola miejskich obszarów funkcjonalnych ze względu na znaczenie w procesach rozwojowych. Odnosi się to zwłaszcza do obszarów metropolitalnych, których wyznaczenie zostało uznane za zadanie samorządu regionalnego zapisane już w ustawie o planowaniu i zagospodarowaniu przestrzennym z 2003 r. Jednak KPZK 2030 wskazuje także na znaczenie obszarów funkcjonalnych tworzących się przy mniejszych miastach, które łączą się z otaczającymi je obszarami wiejskimi licznymi powiązaniami funkcjonalnymi. W KPZK 2030 zostały wyróżnione jeszcze dwa możliwe i potrzebne typy miejskich obszarów funkcjonalnych: regionalne - związane zasadniczo z miastami liczącymi więcej niż 100 tys. mieszkańców, a nie pełniące roli stolic województw oraz subregionalne - tworzące się wokół miast o liczbie mieszkańców między 50 a 100 tys. Wyróżnienie podanych wyżej obszarów funkcjonalnych może przynieść efekty rozwojowe, w opinii autora, wtedy, gdy powstaną na nich odpowiednie struktury planujące i koordynujące działania związane $z$ dostarczaniem usług publicznych czy rozbudową infrastruktury technicznej i społecznej niezbędnęj dla podtrzymywania rozwijających się powiązań funkcjonalnych. Dla swojego rozwoju, zwiększania spójności i wzmacniania konkurencyjności obszary funkcjonalne potrzebują part- 
nerstw obejmujących lokalną, a w niektórych wypadkach także regionalną administrację samorządową, partnerów gospodarczych i społecznych.

\section{Działania Kancelarii Prezydenta RP, MAC, MRR oraz ZMP i innych stowarzyszeń samorządowych}

Z przedstawionymi już tendencjami zbieżne są tė̇ propozycje zawarte w projekcie tzw. „prezydenckiej ustawy o samorządzie”. W pierwotnej wersji, zaproponowanej w 2011 r., zatytułowanej „Projekt ustawy o wzmocnieniu udziału mieszkańców w samorządzie terytorialnym, współdziałaniu gmin, powiatów i województw oraz o zmianie niektórych ustaw" przedstawiono cały szereg różnorodnych inicjatyw promujących rozwiązania instytucjonalne wspomagające możliwości współpracy różnych aktorów w dziedzinie wspierania rozwoju lokalnego i regionalnego. Pierwotna wersja w trakcie dyskusji i konsultacji uległa znacznej ewolucji i po zmianach otrzymała nazwę „Ustawa o współdziałaniu w samorządzie terytorialnym na rzecz rozwoju lokalnego i regionalnego oraz o zmianie niektórych ustaw"6. Nie wiemy obecnie, jaka będzie przyszłość tych propozycji, ale w wersjach przedstawianych do konsultacji ze strony ekspertów zaproszonych przez prezydenta do prac nad ustawą widać wyraźnie chęć zapewnienia polskim JST większych instytucjonalnych możliwości budowania partnerstw na poziomie lokalnym. Interesującymi propozycjami w tym zakresie są ,zespoły współpracy terytorialnej", które w założeniu miałyby służyć nawiązywaniu współpracy sąsiadujące gminy i powiaty w celu wspólnej realizacji zadań publicznych. Proponuje się, aby w zakres możliwych do podejmowania zadań przez zespoły wchodziły oprócz klasycznych usług publicznych także zagadnienia związane ze wspólnym planowaniem strategicznym i przestrzennym oraz np. wspólna promocja i polityka proinwestycyjna.

W podobnym kierunku do „prezydenckiej” propozycji ustawy samorządowej zmierzają aktualne działania podejmowane przez Ministerstwo Administracji i Cyfryzacji (MAC). Po dokonaniu w 2012 r. oceny funkcjonowania jednostek samorządu terytorialnego oraz po przeprowadzeniu konsultacji „Zielonej księgi obszarów metropolitalnych" " przedstawiono rozwiązania zakładające m.in. wspieranie oddolnie budowanej współpracy samorządów i dążenie do umożliwienia tworzenia związków gminno-powiatowych. Analizy wykazały, że sytuacja najmniejszych gmin, liczących poniżej 5 tys. mieszkańców, będzie coraz trudniejsza pod względem finansowym z powodu wyraźnie postępującej w nich depopulacji i jednocześnie rosnących kosztów ich funkcjonowania przy rosnących

${ }_{6}$ Projekt jest dostępny na: http://www.prezydent.pl/prawo/ustawy/zgloszone/art, 18,projekt-ustawy-samorzadowej.html (dostęp: 6.09.14).

7 Dokument zawierający ocenę jest dostępny na: https://mac.gov.pl/files/ocena-sytuacji-samorzadow-lokalnych.pdf (dostęp: 6.09.14).

8 Dokument ten jest dostępny na: https://mac.gov.pl/zielona-ksiega-obszarow-metropolitalnych/ (dostęp: 6.09.14). 
wydatkach związanych z zapewnieniem współcześnie wymaganych standardów usług publicznych. Wobec dostrzeganych wyzwań MAC zauważa wyraźną potrzebę łączenia najmniejszych gmin oraz "gmin obwarzankowych" z gminami rdzeniowymi tak aby obniżyć koszty i podnosić jakość świadczonych przez nie usług. Uruchomienie współpracy tych gmin i gmin na obszarach metropolitalnych jest uznawane przez MAC za bardzo pilne i konieczne dla racjonalizacji całego sektora finansów publicznych. Zgłaszany kierunek zmian w przedstawionej w $2013 \mathrm{r}$. „Białej księdze obszarów metropolitalnych” zakładał zwiększenie swobody JST w wyborze formy organizacyjnej przy wspólnym świadczeniu usług publicznych.

Formą wspierania współpracy samorządów są projekty uruchamiane przez Ministerstwo Rozwoju Regionalnego (kontynuowane po przekształceniach w 2014 r. przez Ministerstwo Infrastruktury i Rozwoju MIR) skierowane do partnerstw samorządowych. Działania te kładą nacisk na promowanie współpracy jednostek samorządu terytorialnego w zakresie koordynacji działań i podejmowania wspólnej aktywności prorozwojowej. Projekty te dają partnerstwom możliwość korzystania z zewnętrznych środków. Z reguly nie ma w nich sztywnych ograniczeń co do formy partnerstwa czy długości wcześniejszej współpracy. Istnieje jednak zagrożenie, że zgłaszające się partnerstwa podejmują współdziałanie wyłącznie w celu skorzystania $z$ funduszy zewnętrznych, a po ustaniu zewnętrznego finansowania współpraca zaniknie.

Przykładem inicjatyw prowadzonych obecnie przez MIR jest program „Rozwój miast poprzez wzmacnianie kompetencji jednostek samorządu terytorialnego, dialog społeczny oraz współpracę z przedstawicielami społeczeństwa obywatelskiego" współfinansowany z środków MF EOG 2009-2014. Za cel w tym programie uznano „Osiągniecie lepszej spójności społecznej i gospodarczej na szczeblu krajowym, regionalnym i lokalnym poprzez wypracowanie mechanizmów efektywnej współpracy międzysamorządowej i międzysektorowej”. Częścią tego programu jest projekt realizowany przez ZMP przy wspólpracy ZPP i ZGWRP pod nazwą „Budowanie kompetencji do współpracy międzysamorządowej i międzysektorowej jako narzędzi rozwoju lokalnego i regionalnego"10. Celem głównym tego projektu w pierwszej fazie była pomoc partnerstwom ubiegającym się o granty w komponencie konkursowym Programu Regionalnego MRR w przygotowaniu dobrych wniosków aplikacyjnych. Oprócz realizacji tego celu, a zwłaszcza $w$ drugiej fazie, projekt koncentruje się na pomocy $w$ rozwijaniu kompetencji do współpracy międzysamorządowej i międzysektorowej w trakcie realizacji projektów wspieranych grantami MRR. Prowadzi się też monitoring funkcjonowania partnerstw uczestniczących w programie, który powinien pozwolić na sformulowanie wniosków legislacyjnych dotyczących usunięcia problemów formalno-prawnych w realizacji projektów partnerskich przez jednostki samorządu. W ramach projektu uruchomiono także szkolenia dla przedstawicieli partnerstw w celu doskonalenia umiejętności interpersonalnych niezbędnych do rozwijania

9 Dokument ten jest dostępny pod adresem: https://mac.gov.pl/files/wp-content/uploads/2011/12/BK.pdf (dostęp: 6.09.14).

10 Informacje o projekcie są dostępne pod adresem: http://www.miasta-polskie.pl/strona-72-projekt_norweski_2.html (dostęp: 16.09.14). 
kultury organizacyjnej otwartej na współpracę. Końcowym efektem projektu ma być szerokie upowszechnienie wśród ogółu jednostek samorządu terytorialnego w kraju wiedzy i doświadczeń z zakresu współpracy międzysamorządowej i międzysektorowej.

\section{Wyznaczanie obszarów funkcjonalnych a zasięgi działania partnerstw międzysamorządowych}

Ustawa o planowaniu i zagospodarowaniu przestrzennym z 27 marca $2003 \mathrm{r}$. wprowadziła pojęcia obszarów problemowych i metropolitalnych, które można uznać za szczególne rodzaje obszarów funkcjonalnych, i przypisała samorządom wojewódzkim zadanie wyznaczenia tych obszarów. Ustawa nie wprowadzała zasad wyznaczania tych obszarów, pozostawiając tę kwestię w gestii samorządów wojewódzkich. Wypełniając to zadanie w zakresie wyznaczania obszarów metropolitalnych, kierowały się one dostępnymi danymi statystycznymi pozwalającymi wskazać zasięg występowania zjawisk społeczno-gospodarczych świadczących o powiązaniach funkcjonalnych między ośrodkami metropolitalnymi a otaczającymi terenami. Przykładem takiego postępowania było wyznaczenie poznańskiego obszaru metropolitalnego ${ }^{11}$ w $2006 \mathrm{r}$.

Samorząd województwa wielkopolskiego, rozumiejąc znaczenie obszarów funkcjonalnych $w$ realizacji polityki rozwoju w świetle podejścia terytorialnego, przygotował opracowanie ${ }^{12}$ zawierające zasady i kryteria wyznaczania obszarów funkcjonalnych na swoim terenie. Zaproponowano wskaźniki i kryteria o charakterze statystycznym, funkcjonalnym lub geograficznym, które posłużyly do wyznaczenia kilku poziomów obszarów funkcjonalnych w województwie. Opracowanie to jest realizacją ustaleń „Zaktualizowanej strategii rozwoju województwa wielkopolskiego do roku 2020", która w swoich zapisach podkreśla znaczenie dla przyszłego rozwoju poznańskiego obszaru metropolitalnego obszarów funkcjonalnych ośrodków subregionalnych i innych ośrodków miejskich.

Ostatnia aktualizacja z $2014 \mathrm{r}^{13}$ ustawy o planowaniu i zagospodarowaniu przestrzennym, spowodowana uchwaleniem ustawy o zmianie ustawy o zasadach prowadzenia polityki rozwoju oraz niektórych innych ustaw ${ }^{14}$, zastępuje pojęcia obszarów problemowych i metropolitalnych pojęciami obszary funkcjonalne i miejskie obszary funkcjonalne ośrodków wojewódzkich. Jednocześnie ustawa określa rolę poszczególnych poziomów władz publicznych w wyznaczaniu zasię-

11 Informacje o zastosowanych kryteriach zawarte są pod adresem: http://www.wbpp.poznan.pl/ opracowania/POM/POM.html (dostęp: 16.09.14).

12 Opracowanie jest dostępne pod adresem: http://www.wbpp.poznan-pl/index.php?option=com content\&task = blogcategory\&id $=19 \& I t e m i d=48$ (dostęp: 16.09.14).

13 Dostępna pod adresem: isap.sejm.gov.pl/Download?id=WDU20030800717\&type =3 (dostęp: 16.09.14).

14 Dostępna pod adresem: isap.sejm.gov.pl/Download;jsessionid...?id=WDU20140000379 _..1 (dostęp: 16.09.14). 
gu obszarów funkcjonalnych, które są istotnym elementem realizacji polityki rozwoju państwa.

Aktualne dokumenty kształtujące politykę rozwoju i politykę przestrzenną w Polsce uwzględniają założenia nowej polityki rozwoju oraz polityki ukierunkowanej terytorialnie, które zostały przedstawione wcześniej. Potrzebę rozwijania współdziałania w ramach micjskich obszarów funkcjonalnych podkreśla projekt Krajowej Polityki Miejskiej ${ }^{15}$ przygotowany w 2014 r. Nowym instrumentem realizacji polityki rozwoju w Polsce od 2014 r. stały się zintegrowane inwestycje terytorialne (ZIT) ${ }^{16}$ będące ważnym elementem wdrażania polityki spójności EU. Celem ZIT jest promowanie partnerskiego modelu współpracy różnych jednostek administracyjnych tworzących obszar funkcjonalny poprzez realizację wspólnych przedsięwzięć. Wyznaczanie granic obszarów dla ZIT można potraktować jako test podejścia do realizacji tego celu i prognostyk przyszłych działań przy wyznaczaniu obszarów funkcjonalnych. Należy podkreślić, że obszary te nie mają służyć celom poznawczym, ale mają pomóc stworzyć wspólną wizję rozwoju najważniejszych obszarów zurbanizowanych i uruchomić wspólne inwestycje ważne dla całego obszaru. Obszary te mają obejmować terytorium jednostek samorządu terytorialnego podzielone granicami administracyjnymi, ale powiązane organizacyjnie i funkcjonalnie.

W skali kraju do realizacji ZIT na obszarach funkcjonalnych ośrodków wojewódzkich zaproponowano zasięgi tych obszarów w oparciu o jednorodne podejście. Na zamówienie MRR przygotowano opracowanie (MRR 2013), w którym, korzystając z siedmiu wskaźników o charakterze funkcjonalnym, społeczno-gospodarczym i morfologicznym, wyznaczono obszary funkcjonalne wokół 18 ośrodków wojewódzkich. Przewidziano też na poziomie regionalnym możliwość niewielkich modyfikacji wyznaczonych centralnie zasięgów dla realizacji ZIT w celu wprowadzenia korekt uzasadnionych zapisami planistycznymi związanymi z regionalnymi strategiami rozwoju lub dodatkowymi kryteriami funkcjonalnymi. Nie wspominano o możliwych korektach wynikających $z$ chęci wzmocnienia zdolności kooperacyjnych jednostek samorządu terytorialnego związanych $z$ dotychczasowym funkcjonowaniem partnerstw międzysamorządowych w ramach obszarów funkcjonalnych.

W praktyce wyznaczania obszarów realizacji ZIT samorządy regionalne rzadko decydowały się na modyfikację centralnie przygotowanej delimitacji. Nawet w wypadku niektórych długo istniejących partnerstw i mających różnorodne pola aktywności, takich jak działający od 1999 r. na obszarze funkcjonalnym Gorzowa Związek Celowy Gmin MG6, nie udało się przekonać samorządu województwa do poszerzenia o jedną gminę, członka związku, centralnie wyznaczonego zasięgu obszaru realizacji ZIT. W województwie pomorskim zaproponowany przez ministerstwo zasięg obszaru realizacji ZIT stał się okazją do kompromisu i podjęcia wspólpracy przez konkurujące partnerstwa międzysamorządowe, które powstały

15 Dostępna pod adresem: http://www.mir.gov.pl/rozwoj_regionalny/polityka_regionalna/rozwoj_ miast/kpm/strony/start.aspx (dostęp: 16.09.14).

16 Zasady realizacji ZIT są przedstawione na stronie: http://www.mir.gov.pl/aktualnosci/polityka_ rozwoju/Strony/Zasady_ZIT.aspx (dostęp: 16.09.14). 
osobno wokół Gdańska ${ }^{17}$ i Gdyni18. W wielu innych województwach zaproponowane odgórnie zasięgi obszarów realizacji ZIT były początkiem powołania nowych partnerstw międzysamorządowych, np. w postaci stowarzyszeń czy porozumień. Wcześniej bez wizji skorzystania z europejskich środków finansowych na inwestycje potrzebne na obszarach funkcjonalnych jednostki samorządu terytorialnego nie potrafiły nawiązać trwałej współpracy.

W niektórych województwach, gdzie istniała nastawiona na koordynację rozwoju długotrwała współpraca międzysamorządowa na metropolitalnych obszarach funkcjonalnych, udało się zmodyfikować centralnie zaproponowane zasięgi realizacji ZIT, tak aby były one dopasowane do zasięgu działania stowarzyszeń samorządowych oddolnie powołanych dla koordynacji rozwoju w ramach obszarów metropolitalnych. Taka sytuacja miała miejsce w województwie wielkopolskim i zachodniopomorskim, gdzie działają Stowarzyszenie Metropolia Poznań od 2011 r. i Stowarzyszenie Szczecińskiego Obszaru Metropolitalnego od 2009 r. Stowarzyszenia te po negocjacjach zostały zaproponowane przez władze regionalne jako instytucje odpowiedzialne za realizację przyszłych ZIT i przygotowały strategie dla ich realizacji a wcześniej opracowały strategie rozwoju dla swoich obszarów metropolitalnych. Takie rozwiązania należy uznać za właściwe, ponieważ pozwalają utrzymać zaufanie między partnerami samorządowymi, przyczyniają się do rozwoju obszaru metropolitalnego przy wykorzystaniu istniejącej już kultury organizacyjnej nastawionej na współpracę JST oraz wspierają praktyczne rozwijanie umiejętności wspólnego działania.

Także przy ustalaniu przez władze regionalne zasięgów obszarów funkcjonalnych na niższych poziomach, np. dla ośrodków subregionalnych, warto uwzględniać ich dotychczasowe doświadczenie we współpracy, a nie tylko korzystać ze wskaźników statystycznych. Jest to szczególnie istotne przy podejmowaniu decyzji o zaliczeniu poszczególnych JST do obszarów, dla których przewiduje się zewnętrzne wsparcie w celu pobudzenia ich rozwoju. Warto doceniać oddolne inicjatywy kooperacyjne i wspierać rozwój zaufania między partnerami. Przykładowo w województwie wielkopolskim podjęto cenną inicjatywę wyznaczenia obszarów strategicznej interwencji dla obszarów funkcjonalnych ośrodków subregionalnych. Przy ustalaniu ich zasięgów kierowano się zasadami i kryteriami zawartymi w specjalnie przygotowanym opracowaniu (ZWL 2013), w którym wykorzystano wskaźniki ilustrujące powiązania funkcjonalne, zasięg powiązań komunikacyjnych, liczbę połączeń komunikacją zbiorową, zmiany liczby ludności i zmianę powierzchni terenów zurbanizowanych. Podejście takie jest jak najbardziej wskazane, gdy na danym terenie chcemy poznać zasięg oddziaływania ośrodka miejskiego i gdy brakuje inicjatyw kooperacyjnych międzysamorządowych. Jednak gdy celem wyznaczenia takiego obszaru jest koordynacja rozwoju i uruchomienie wspólnych inwestycji, warto przyjrzeć się także doświadczeniom JST w prowadzeniu współpracy. W wypadku województwa wielkopolskiego zastosowanie tylko jednolitych wskaźników ograniczyło zasięg współpracy Leszna z otaczającymi gminami, która w ostatnich latach rozwijała się w zakresie usług

17 Stowarzyszenie Gdański Obszar Metropolitalny utworzone w $2011 \mathrm{r}$.

18 Metropolitalne Forum Wójtów, Burmistrzów i Prezydentów NORDA z 2011 r. 
komunalnych, promocji i turystyki. Leszno wraz z partnerami z powiatu ziemskiego i pięciu gmin podpisało porozumienie o partnerstwie i realizuje $z$ powodzeniem projekt polegający na opracowaniu strategii rozwoju dla partnerstwa ${ }^{19}$. Przy inicjatywach wojewódzkich, takich jak wyznaczanie obszarów interwencji strategicznej i zakładających promowanie współdziałania JST, warto wykorzystywać już zbudowany kapitał społeczny.

\section{Wnioski}

Umiejętność oddolnego współdziałania w jednostkach samorządu terytorialnego jest w krajach rozwiniętych powszechnie doceniana i jest uważana za istotny element kultury organizacyjnej związanej z rozwijaniem wielopoziomowego współrządzenia (multi-level governance), która jest obecnie uznawana za wiodącą koncepcję funkcjonowania administracji publicznej. Niestety, stosunkowo rzadko spotykamy takie podejście w budowaniu partnerstw, co może być spowodowane nie tylko brakiem chęci do współpracy, ale także niedostatkiem umiejętności w dziedzinie organizowania współdziałania. Widać to wyraźnie w Polsce, np. po niewielkiej liczbie 13 partnerstw międzysamorządowych, które zgłosiły się w 2014 r. do konkursu „Razem dla rozwoju” organizowanego przez stowarzyszenia samorządowe 20 .

Dotychczasowe obserwacje wskazują, że potrzebne jest kształcenie kompetencji menedżerskich $w$ zakresie organizowania i prowadzenia partnerstw międzysamorządowych oraz budowanie wiedzy u polityków samorządowych o moźliwościach i korzyściach wynikających z takiej współpracy dla jednostek administracji, ale przede wszystkim dla mieszkańców. Korzyści te są widoczne głównie w obrębie obszarów funkcjonalnych. Podejmowanie oddolnych działań partnerskich powinno być wspierane przez działania z poziomu regionalnego i ministerialnego.

We wszystkich sytuacjach, które wymagają wyznaczania granic obszarów funkcjonalnych przez rząd lub władze regionalne, takich jak wyznaczenie zasięgu dla uruchomienia zintegrowanych inwestycji terytorialnych lub obszarów strategicznych interwencji, cenne jest uwzględnienie zasięgu istniejących partnerstw. Warto docenić oddolne inicjatywy, które doprowadziły jednostki samorządu terytorialnego do podjęcia współpracy. Z reguły zawiązanie partnerstw wymaga czasu, zaangażowania polityków, rozwinięcia umiejętności pokonywania pojawiających się trudności, budowania realnych rozwiązań instytucjonalnych. Są to bardzo ważne zasoby dla prowadzenia wspólnych projektów czy dostarczania wspólnie usług publicznych, które powstają w dłuższym czasie w wyniku zdobywania doświadczeń i dokonywania analiz osiąganych wyników. Szkoda, aby decyzjami na poziomie krajowym czy regionalnym przekreślać dorobek partnerstw oddolnie stworzonych przez jednostki samorządu terytorialnego. Wspólnym

19 Ze strategią opracowaną w ramach tego projektu można zapoznać się na stronie: www.leszno.pl/ DATA/pliki/nawrocka/ofal_strategia_ostateczna.pd (dostęp: 15.11.14).

20 Informacje o konkursie są zawarte nä stronie: http://www-miasta-polskie.pl/aktualnosc-1038-finalisci_konkursu_samorzadowy_lider.html (dostęp: 15.11.14). 
celem działań całej administracji publicznej powinno być budowanie zaufania między podmiotami partnerstwa. Uwzględnienie zasięgów działania istniejących partnerstw międzysamorządowych przy wyznaczaniu obszarów funkcjonalnych będzie sprzyjać poprawie sprawności funkcjonowania programów interwencji na tych obszarach.

\section{Literatura}

Ansell C. Gash A. 2008. Collaborative governance in theory and practice. Journal of Public Administration Research and Theory, 18(4): 543-571.

Chądzyński J., Nowakowska A., Przygodzicki Z. 2007. Region i jego rozwój w warunkach globalizacji. CeDeWu, Warszawa.

Czyż T. 2009. Koncepcje aglomeracji miejskiej i obszaru metropolitalnego w Polsce, w: Przegląd Geograficzny, 81, 4: 445-459.

Dolnicki B. 2012. Samorząd terytorialny. Wolters Kluwer, Warszawa.

EC 2008. Green Paper on Territorial Cohesion: Turning Territorial Diversity into Strength. Commision of the European Communinities, Brussels.

Florida R. 2005. The world is spiky. Atlantic Monthly, October.

Grosse T.G. 2008. Rozważania o przyszłości polityki spójności Unii Europejskiej. [W:] P. Jakubowska, A. Kukliński, P. Żuber (red.), Problematyka przyszłości regionów. W poszukiwaniu nowego paradygmatu, Ministerstwo Rozwoju Regionalnego, Warszawa.

Hulst R. i in. 2009. Institutional Shifts In Inter-Municipal Service Delivery. An analysis of developments in eight Western European countries. Public Organization Rev., 9: 263-285.

Hulst R., van Montfort A. 2012. Institutional features of inter-municipal cooperation: Cooperative arrangements and their national contexts, Public Policy and Administration, 27(2) s. 121-144.

Kisiała W., Stępiński B. 2013. Rola obszarów metropolitalnych w polityce regionalnej i rozwoju regionalnym. Uniwersytet Ekonomiczny w Poznaniu, Poznań.

Komisja Europejska (KE). 2010. EUROPA 2020 Strategia na rzecz inteligentnego i zrównoważonego rozwoju sprzyjającego włączeniu społecznemu. Bruksela.

Koncepcja Przestrzennego Zagospodarowania Kraju 2030 (KPZK 2030). 2012.

Krajowa Strategia Rozwoju Regionalnego 2010-2020 - regiony, miasta i obszary wiejskie" (KSRR 2020). 2010.

Lackowska M. 2009. Why is voluntary co-operation condemned to failure? Reflections on the Polish and German background. Lex Localis, 7: 347-369.

Lisowski A., Grochowski M. 2008. Procesy suburbanizacji, uwarunkowania, formy i konsekwencje. [W:] Ekspertyzy do koncepcji przestrzennego zagospodarowania kraju 2008-2033. T. 1, Ministerstwo Rozwoju Regionalnego, Warszawa.

Markowski T., Marszał T. 2006. Metropolie, obszary metropolitalne, metropolizacja. Problemy i pojęcia podstawowe. KPZK PAN, Warszawa.

MRR 2009. Identyfikacja i delimitacja obszarów problemowych i strategicznej interwencji w Polsce. Wnioski z analiz. Raporty 2009, Ministerstwo Rozwoju Regionalnego Instytut Badań Strukturalnych, Warszawa.

MRR 2013. Zasady uwzględniania wymiaru miejskiego polityki spójności UE, w tym realizacja zintegrowanych inwestycji terytorialnych. Programowanie perspektywy finansowej na lata 2014-2020. Warszawa.

Nowak J.F. 2012. Rozwój form i zakresu współpracy jednostek samorządu terytorialnego z partnerami zewnętrznymi. Prace z Gospodarki Przestrzennej, Zeszyty Naukowe, 247. Wydawnictwo Uniwersytetu Ekonomicznego w Poznaniu.

Nowak J.F., Perska A. 2014. Zaangażowanie partnerów samorządowych aglomeracji poznańskiej w budowanie metropolii Poznań. Studia Miejskie, 13. Wydawnictwo Uniwersytetu Opolskiego.

Nowak M.J. 2010. Polityka przestrzenna w polskich obszarach metropolitarnych.

OECD 2009. Regions matter: economic recovery, innovation and sustainable growth. 
Olechnicka A., Wojnar K. 2013. Terytorialny wymiar rozwoju Polska z perspektywy badań ESPON. Wydawnictwo Naukowe Scholar.

Piasecki A. 2009. Samorząd terytorialny i wspólnoty lokalne. Wydawnictwo Naukowe PWN, Warszawa.

Przygodzicki Z. 2007. Region i klasyczne teorie jego rozwoju. [W:] Region i jego rozwój w warunkach globalizacji. CeDeWu Warszawa, s. 39-62.

Smętkowski M., Jałowiecki B., Gorzelak G. 2009. Obszary metropolitalne w Polsce: problemy rozwojowe i delimitacja. Raporty i Analizy EUROREG 1.

Smętkowski M. 2013. Miasta jako bieguny wzrostu. [W:] A. Olechnicka, K. Wojnar (red.), Terytorialny wymiar rozwoju. Polska z perspektywy badań ESPON. Wydawnictwo Naukowe Scholar.

Śleszyński P. 2013. Delimitacja miejskich obszarów funkcjonalnych stolic województw. Przegląd Geograficzny, 85, 2: 173-197.

Winiarski B., Winiarska F. 2006. Polityka regionalna. [W:] B. Winiarski (red.), Polityka gospodarcza. Wydawnictwo Naukowe PWN, Warszawa.

\title{
Inter-municipal cooperation as an element of territorially- oriented development policy and its role as a factor of delimitation of functional urban areas
}

\begin{abstract}
The paper includes a discussion of the territorially oriented development policy as a currently leading concept of the development which promote inter-municipal cooperation and collaboration with bodies from social and private sector. The focus is on highlighting the importance of taking into account the operating range of inter-municipal partnerships in determining the boundaries of municipal functional areas that play a key role in the implementation of the territorially oriented development policy.

In the beginning are presented assumptions of new regional policy developed since the nineties of the twentieth century. This policy, accentuated by the European Union, seeks to promote the competitiveness of areas among others by supporting the cooperation of the different sectors within the urban functional areas. In Poland, along with the development of sub-urbanization is increasing need to coordinate activities within the municipal functional areas. Local government units form an inter-municipal partnerships to coordinate development policy and jointly provide public services. The Government, in accordance with the European Union policy, is developing programs to support the integration of local authorities among others by promoting cooperation between local government units and the delimitation of the boundaries of urban areas for which wants to run specific investment projects. The author proposes that the setting ranges for these interventions take into account the existing partnership between the self-governments in order to benefit existing experience and trust between the representatives of the local authorities. It is important to protect the capital of cooperation, which was built on part of the emerging municipal functional areas.

This paper also presents examples of different treatment by the regional authorities existing inter-municipal partnerships in process to launch in Poland integrated territorial investments as part of the European program. Only in some regions were appreciated the importance of the existing efforts made to determine eg. common strategy, development projects and organize joint municipal services.
\end{abstract}

Key words: Territorially oriented development policy, urban functional areas of inter-municipal partnerships 